\title{
Chemomechanical Caries Removal: A Conservative and Pain-Free Approach
}

\author{
Mithra N Hegde and Abhishek MA* \\ Department of Conservative Dentistry and Endodontics, AB Shetty Memorial Institute of Dental Sciences, India
}

Submission: May 08, 2017; Published: May 26, 2017

"Corresponding author: Dr. Abhishek.MA, Department of Conservative Dentistry and Endodontics, AB Shetty Memorial Institute of Dental Sciences, Nithyanandha Nagar, Mangalore-575018, India, Tel: +91-9611846295; Email: docabhi93@gmail.com

\begin{abstract}
Chemomechanical caries removal (CMCR) is a minimally invasive technique of eliminating infected dentin using specific chemical agents and hand instruments. The method of caries removal is based on chemical dissolution. It is mainly indicated to overcome the use of burs and local anaesthesia, causing less discomfort to patients, preserving healthy dentin structure, thereby complying by the concept of minimal intervention dentistry (MID). The chemomechanical caries removal approach had been suggested many decades ago, while interest in exploring these innovative methods have increased in the recent past. The key to this being, its efficiency in eliminating infected dentine without altering the healthy dental tissue and affected dentine while avoiding pulpal irritation and harm to the adjacent oral mucosa. Initial materials tried and tested include sodium hypochlorite, N-monochloroglycine and Caridex. Carisolv is a successful and commonly used agent with naturally occurring amino acids and detector dyes; while Papacarie and Carie-care with natural extract from Papaya tree, give promising result as a CMCR agent of the future. Another experimental solution under development includes Biosolv. However, long term studies are required to evaluate its efficacy in caries removal. The New Carisolv System has incorporated a caries detector gel, specialised hand instruments and minimally invasive burs. Chemomechanical methods can be extremely useful in anxious disables, medically compromised, geriatric and paediatric patients. As a means of preservation of healthy tissue and caries affected dentin, CMCR is possibly much more effective than conventional rotary instrumentation.
\end{abstract}

69

\section{Introduction}

With the increasing trend and need for preserving natural tooth structure while providing a patient friendly environment, Minimal Intervention Dentistry is of great eminence in today's scenario [1]. One of the techniques includes Chemomechanical Caries Removal. As the name suggests, Chemomechanical Caries Removal involves the application of a chemical solution to the carious dentine followed by gentle removal with hand instruments. It has seen to be very efficient in its caries removal effectiveness while maintaining its minimal invasive potential. It is based on biological principles which involves removal of only the infected dentine while retaining the affected dentin [2]. The chemical agents used can be broadly classified into sodium hypochlorite based agents and enzymatic agents.

\section{Sodium hypochlorite based agents}

These agents containsodium hypochlorite derivatives, which chlorinate and disrupt the hydrogen bonds of partially degraded collagen in carious dentine which are then removed using hand instruments [2]. In the early 1970's, 5\% NaOCl solution was used, but was rendered unstable [3] and non-specific [4]. Various attempts to overcome this problem have been made by adding amino acids to sodium hypochlorite.

\section{GK-101/N-monochloroglycine (1976)}

Goldman and Kronman decided to incorporate sodium hypochlorite into Sorensen's buffer (containing glycine, sodium chloride and sodium hydroxide) to reduce the corrosiveness [5]. This involved the chlorination of glycine in the denatured collagen to form $\mathrm{N}$-monochloroglycine (NMG) and the reagent subsequently became known as GK-101 [6]. GK-101 acts by disrupting the organic structure of dentine by converting hydroxyproline (which stabilizes collagen) to pyrrole-2carboxyglycine (which is friable and can easily be removed). However, this solution was not very effective in caries removal.

\section{Caridex/GK-101E/N-monochloroaminobutyrate (1984)}

Schutzbank found that the system was more effective if glycine was replaced by amino butyric acid [7], which was later 
sold by the brand name Caridex. Solution I contained sodium hypochlorite and Solution II contained glycine, aminobutyric acid, sodium chloride and sodium hydroxide. The action of Caridex on denatured collagen fibrils was similar to that of GK-101, which involved chlorination of the partially degraded collagen in the carious lesion and the conversion of hydroxylproline to pyrrole-2- carboxylic acid [8]. Yip et al suggested a modification using Urea which increased the caries removal potential [9]. Limitations of Caridex were that large volumes of solution were needed (200-500 ml), a delivery system was required and the procedure was very slow $[2,3]$.

\section{Carisolv (1998)}

MediTeam in Sweden developed Carisolv which was in the form of a pink gel that can be applied to the carious lesion with specially designed hand instruments [10]. It is marketed in two syringes, one containing the sodium hypochlorite solution and the other a pink viscous gel which contains three amino acids: lysine, leucine and glutamic acid, together with carboxymethylcellulose to make it viscous and erythrocin dye to make it readily visible in use. Because it is a gel, the volume required is less than $1 \mathrm{ml}$, it is much easier to apply, and there is better contact with the carious lesion [11]. It requires neither heating nor a delivery system.

\section{New Carisolv system (2013)}

It was introduced by Rubicon Life Scienceand includes an advanced gel, a new excavation technique and a new patented caries detector [12]. Special hand excavators with blunt cutting angles and the Komet Bur Technology have been incorporated in this kit. The tissue preserving burs comprise of the ceramic bur CeraBur K1SM and the round polymer bur PolyBur P1. By means of a unique patented technology, the burs offer a considerably more minimally invasive treatment than traditional techniques. The CeraBur helps the dentist to distinguish between healthy and carious tissue in a tactile manner, which is reinforced when used with Carisolv Gel. The disposable PolyBur is softer than healthy dentin and is therefore self-limiting, and can thus be used in treatments close to the pulp. This new system provides an excellent bonding surface for bonded restorations [13].

\section{Enzymatic based agents}

Papacarie and Carie-care have been reported to be effective in removal of caries by the action of the natural extract of pepsin enzyme from the Carica papaya tree $[15,18]$. An experimental product called Biosolv (SFC-V and SFC-VIII) is being developed using pepsin enzyme in a buffered solution [19].

\section{Papacarie gel (2003)}

Bussadori et al introduced Papacarie [14] which consists of papain enzyme (extracted from the latex of leaves and fruits of the green adult Carica papaya tree [15]), chloramine, toluidine blue, salts, preservatives, a thickener, stabilizers and deionized water [14]. The main action depends on the presence of the papain enzyme which is a proteolytic enzyme that causes degradation of proteoglycans in the dentinal matrix [14]. It also has bactericidal and anti-inflammatory actions [16]. The chloramine enhances the removal of denatured tissues [17].

\section{Carie-care (2010)}

It is a more recent solution developed by Uni-Biotech Pharmaceuticals Private Limited, Chennai, India in collaboration with Vittal Mallya Scientific Research Foundation. Even this is a gel-based formulation containing papain enzyme along with the benefits of Clove oil. Papain breaks peptide bonds and involves deprotonation of Cys-25 by His-159. Clove oil is a natural analgesic and anaesthetic [18].

\section{Biosolv}

It is an experimental enzymatic chemomechanical caries removal agent which is not commercially available (coded SFC-V and SFC-VIII). Based on the manufacturer's information, it consists of pepsin enzyme in a phosphoric acid/sodium biphosphate buffer [19]. It is claimed that the phosphoric acid can dissolve the inorganic components of caries-infected dentine, while permitting the pepsin to selectively disrupt the denatured collagen fibres [20]. Meanwhile, this softened mass can then be easily removed by the specially designed plastics instruments (Star V1.3) without affecting sound tissue [19].

\section{Conclusion}

The currently available chemomechanical caries removal methods remove only the infected demineralised dentin while retaining the affected remineralisable dentin. They eliminate the noise of motor driven instruments, reduce pain perception, which in turn reduce the anxiety in patients, especially children, dental phobics and medically compromised patients. These methods can be considered as viable alternatives to conventional rotary caries removal methods [12] with no harm expected either on the healthy dentine or the pulp tissues due to their Conservative and Pain-free approach.

\section{References}

1. Murdoch-Kinch CA, McLean ME (2003) Minimally invasive dentistry. J Am Dent Assoc 134(1): 87-95.

2. Maragakis GM, Hahn P, Hellwig E (2001) Chemomechanical caries removal: a comprehensive review of the literature. Int Dent J 51(4): 291-299.

3. Burke FM, Lynch E (1995) Chemomechanical caries removal. J IrDent Assoc 41: 10-14.

4. Hand RE, Smith ML, Harrison JW (1978) Analysis of the effect of dilution on the necrotic tissue dissolution property of sodium hypochlorite. J Endod 4(2): 60-64.

5. Goldman M, Kronman JH (1976) A preliminary report on a chemomechanical means of removing caries. J Am Dent Assoc 93(6): 1149-1153.

6. Kurosaki N, Sato Y, Iwaku M, Fusayama T (1977) Effect of acarious dentin softener on the dentin and pulp. J Prosthet Dent 38(2): 169-173.

7. SG Schutzbank, J Galaini, JH Kronman, M Goldman, RE Clark (1978) A comparative invitro study of GK-101 \& GK-101E in caries removal. JDR 57(9-10): 861-864. 
8. Beeley JA, Yip HK, Stevenson AG (2000) Chemochemical caries removal: a review of the techniques and latest developments. Br Dent J 188(8): 427-430.

9. HK Yip, AG Stevenson, JA Beeley (1995) An improved reagent for chemomechanical removal of dental caries in permanent \& deciduous teeth: an invitro study. J Dent 23(4): 197-204.

10. Ericson D, Zimmerman M, Raber H, Gotrick B, Bornstein R, et al (1999) Clinical evaluation of efficacy and safety of a new method for chemomechanical removal of caries. A multi-centre study. Caries Res 33(3): 171-177.

11. Albrektsson T (2001) Tissue preservation in caries treatment. London:Quintessence : 159.

12. Hamama H,C Yiu, M Burrow (2014) Current update of chemomechanical caries removal methods. Australian dental journal 59(4): 446-456.

13. Fure S, Lingstro"m P (2004) Evaluation of the chemomechanical removal of dentine caries in vivo with a new modified Carisolvgel. Clin Oral Investigations 8: 139-144.

14. Bussadori SK, Castro LC, Galvao AC (2005) Papain gel: a new chemomechanical caries removal agent. J Clin Pediatr Dent 30(2): 115119.

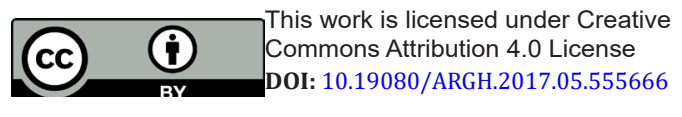

15. Looze Y, Boussard P, Huet J, Vandenbusche G, Azarkan M, et al. (2009) Purification and characterization of a wound-inducible thaumatin-like protein from the latex of Carica papaya. Phyto chemistry 70(8): 970978.

16. Fusayama $\mathrm{T}$ (1979) Two layers of carious dentin: diagnosis and treatment. Oper Dent 4(2): 63-70.

17. Botelho Amaral FL, Martao Florio F, Bovi Ambrosano GM, Basting RT (2011) Morphology and micro tensile bond strength of adhesive systems to in situ-formed caries-affected dentin after the use of a papain-based chemomechanical gel method. Am J Dent 24(1): 13-19.

18. Suzan Sahana, Aron Arun Kumar Vasa, Divya Geddam, Vamsi Krishna Reddy, Sowjanya Nalluri, et al. (2016) Effectiveness of Chemomechanical Caries Removal Agents Papacarie ${ }^{\circledR}$ and CarieCare TM in Primary Molars: An invitro Study. Journal of International Society of Preventive \& Community Dentistry 6(4): 391.

19. Clementino-Luedemann TN, Dabanoglu A, Ilie N, Hickel R,Kunzelmann KH (2006) Micro-computed tomographic evaluation of a new enzyme solution for caries removal in deciduous teeth. Dent Mater J 25(4): 675683.

20. Neves Ade A, Coutinho E, De Munck J, Van Meerbeek B (2011) Caries removal effectiveness and minimal-invasiveness potential of cariesexcavation techniques: a micro-CT investigation. J Dent 39(2): 154-162.

\section{Your next submission with JuniperPublishers will reach you the below assets}

- Quality Editorial service

- Swift Peer Review

- Reprints availability

- E-prints Service

- Manuscript Podcast for convenient understanding

- Global attainment for your research

- Manuscript accessibility in different formats

( Pdf, E-pub, Full Text, audio)

- Unceasing customer service

Track the below URL for one-step submission https://juniperpublishers.com/online-submission.php 